\title{
GLACIOLOGICAL NOTES FROM SUKKERTOPPEN, WEST GREENLAND
}

\author{
By P. W. F. Gribbon \\ (Department of Physics, University of St. Andrews, St. Andrews, Scotland)
}

\begin{abstract}
The retreat of a glacier front at Sukkertoppen, West Greenland, has been related by lichen size measurements to the lowering of the snow level in the accumulation region of the glacier. The altitudes of two Quaternary marine shell beds near Sukkertoppen have been measured and the shell fauna contained in them has been identified. The behaviour of two adjacent ice-dammed lakes is also discussed.
\end{abstract}

RÉSumé. Notes glaciologiques de Sukkertoppen, Groenland ouest. Le retrait du front d'un glacier à Sukkertoppen, Groenland ouest, a été lié par des mesures de dimension de lichens à l'abaissement de la ligne de neige dans la zone d'accumulation du glacier. Les altitudes de deux lits quaternaires de coquillages marins près de Sukkertoppen ont été mesurées et leur faune identifiée. Le comportement des deux lacs glaciaires adjacents est aussi discuté.

Zusammenfassung. Glaziologische Beobachtungen auf Sukkertoppen, West-Grönland. Der Rückzug einer Gletscherfront auf Sukkertoppen, West-Grönland, wurde durch Messung von Flechtengrössen mit der Abnahme der Schneehöhe im Akkumulationsgebiet des Gletschers in Verbindung gebracht. Die Höhe zweier quartärer Ablagerungen von Meeresmuscheln wurde gemessen und die darin enthaltene Muschelfauna bestimmt. Weiter wird das Verhalten zweier benachbarter, durch Eis aufgestauter Seen untersucht.

THIs note discusses some points of glaciological interest studied by the author while with the University of St. Andrews expedition to West Greenland in 1965 .

\section{GLacier Recession}

It is possible to obtain an estimate of the time that has elapsed since a glacier started to retreat by measuring the size of certain crustaceous lichens growing on freshly exposed rock surfaces in the glacier foreland (Beschel, 196r). The longer the time that has elapsed since the recession, the larger and hence the older will be the lichens growing in the foreland. If the growth rate of the lichen under the climatic conditions of the foreland is known, the date at which the lichen started to grow on the rock surface can be estimated.

The present lichenometric work shows that the terminal moraines of a glacier can reflect the changes that take place in the accumulation region of the glacier. The two terminal moraines of a glacier, at lat. $65^{\circ} 43^{\prime} \mathrm{N}$. and north of the Puiartoq inlet of Ikamiut kangerdluarssuat, were compared with the trimline of the highland ice field which fed the glacier. The moraines were of similar development and intensity, about $2 \mathrm{~m}$. high, $70 \mathrm{~m}$. apart and $\mathrm{I} \cdot 35 \mathrm{~km}$. from the present position of the glacier front. The maximum diameters of the lichen thalli of the collective species Rhizocarpon geographicum were measured on the boulders of the moraines and on the rock surface at the trimline, $30 \mathrm{~m}$. above the snow level of the ice field. The moraines were at $180 \mathrm{~m}$. and the trimline at $850 \mathrm{~m}$. above sea-level. The results are given in Table I. The lichen factor is the maximum diameter of a century-old thallus of the species and it was estimated from the data on other West Greenland moraines, including the nearby moraines of Tasuissaq A and B glaciers at lat. $65^{\circ} 34^{\prime} \mathrm{N}$. (Beschel, $196 \mathrm{r}$ ).

\begin{tabular}{|c|c|c|c|}
\hline \multicolumn{4}{|c|}{ TABle I } \\
\hline Locality & $\begin{array}{l}\text { Diameter } \\
\mathrm{mm} .\end{array}$ & $\begin{array}{c}\text { Lichen factor } \\
\text { mm. }\end{array}$ & $\begin{array}{l}\text { Age } \\
\text { yr. }\end{array}$ \\
\hline Moraine, outer & 54 & $30 \pm 3$ & $180 \pm 10$ \\
\hline Moraine, inner & 22 & $30 \pm 3$ & $73 \pm 10$ \\
\hline Trimline, above & 40 & $19 \pm 2$ & $210 \pm 10$ \\
\hline Trimline, below & I5 & $19 \pm 2$ & $80 \pm 10$ \\
\hline
\end{tabular}

The behaviour of the glacier agrees with that of other glaciers in West Greenland (Weidick, 1959). The glacier shows two of the several possible advances of modern times: an advance to its maximum extension at the outer moraine around 1780 and a re-advance to the inner moraine around 1890 . There was no evidence for moraines earlier than $\mathrm{I} 780$ or later than $\mathrm{I} 89 \mathrm{o}$. The extent and rate of the retreat was similar to that of the Tasuissaq A and B glaciers. The most important point was that the lowering of the 
snow level on the ice field was accompanied by, if not followed after a time interval by, a retreat of the glacier front. The climatic fluctuations responsible for a variation in the accumulation-ablation balance of the ice field had indirectly led to the movement of the glacier front.

\section{Quaternary Marine Deposits}

Since the last ice age, fluctuations in sea-level have occurred on the west coast of Greenland (Lawsen, I950). Marine shell beds, formed during a period when the sea-level was constant, were exposed above the present sea-level when a fluctuation occurred. There are five different Quaternary shell-bed sequences along the coast, but only the two youngest ones occur in the Sukkertoppen area.

Two shell-bed terraces occur at Niaqornarssuaq at the head of Ikamiut kangerdluarssuat (lat. $65^{\circ} 47^{\prime} \mathrm{N}$., long. $52^{\circ} 4 \mathrm{I}^{\prime} \mathrm{W}$.). The lower, younger shell bed is at $8 \cdot 5 \pm 0 \cdot 3 \mathrm{~m}$. above the high-tide mark, and the upper bed is at $\mathrm{I} 7 \pm 0.3 \mathrm{~m}$. Very worn and weathered shell specimens on the bed were collected and identified by A. Weidick and Mrs. E. Nordman, Grønlands Geologiske Undersøgelse. The lower bed contained the following species: Pecten islandicus, Mytilis edulis, Tellina calcarea, Saxicava arctica, Mya truncata, Balanus crenatus, Balanus balanus (all abundant); Astarte borealis?, Volutomitra groenlandica, Macoma calcarea, Littorina sp. (all uncommon); Astarte elliptica, Macoma loveni (single specimens). The upper bed contained Balanus crenatus, Balanus balanus (abundant); Pecten islandicus, Saxicava arctica, Mya truncata (uncommon). The age of the upper bed is $5,000-7,000 \mathrm{yr}$. and it was deposited under climatic conditions similar to those of the present day.

\section{ICE-DAMMED LAKES}

There were two small lakes between a mountainside and the ice of the highland ice field at lat. $65^{\circ} 46^{\prime} \mathrm{N}$., long. $52^{\circ} 18^{\prime} \mathrm{W}$. The lakes were $200 \mathrm{~m}$. apart on either side of a rock spur which deflected the flow of the glacier away from the mountainside, and their surfaces were $30-40 \mathrm{~m}$. below the névé surface at $86 \mathrm{om}$. above sea-level. There had been a recent abrupt fall in the surface level of the upper lake by about $15 \mathrm{~m}$., and this had stranded large névé blocks on the gravel scree slope of the mountainside and on the glacier ice, but there had been no corresponding change in the level of the lower lake. The upper lake was ice-free, while the lower lake was covered with close-packed floes. It is therefore concluded that the upper lake was draining into the glacier itself rather than into the lower lake. However, aerial photographs taken in 1948 (Geodætisk Institut, Denmark, 507C-N, 26-29, I8 July 1948) showed a marked difference, with the ice of the upper lake unbroken and the lower lake ice-free except for minor floating floes. In this case it is inferred that the lower lake level was rising rather than falling and possibly re-floating old stranded névé blocks. The recent history of these two lakes therefore indicates that they can show independent and relatively rapid fluctuations in their levels due to changes in their internal drainage pattern into the glacier.

MS. received 25 October 1966

\section{REFERENCES}

Beschel, R. E. 196r. Dating rock surfaces by lichen growth and its application to glaciology and physiography (lichenometry). (In Raasch, G. O., ed. Geology of the Arctic: proceedings of the first international symposium on Arctic geology. Toronto, University of Toronto Press, Vol. 2, p. 1044-62.)

Lawsen, D. 1950. Stratigraphy of marine Quaternary deposits in West Greenland. Meddelelser om Gronland, Bd. ${ }_{1} 5^{1}$, Nr. 1 .

Weidick, A. 1959. Glacial variations in West Greenland in historical time. Part I. Southwest Greenland. Meddelelser om Gronland, Bd. 158 , Nr. 4. 